\title{
Pengaruh Perbedaan Jenis Pakan Alami Jentik Nyamuk, Cacing Darah (Larva Chironomus sp.) dan Moina sp. terhadap Pertumbuhan Ikan Cupang (Betta splendens)
}

Effect of Different Natural Food Type of Mosquito Larvae, Bloodworm Chironomus sp. Larvae) and Moina sp. for the Growth of Betta Fish (Betta splendens)

Nelsiani To'bungan

Fakultas Teknobiologi Universitas Atma Jaya Yogyakarta

Jl. Babarsari No.44 Yogyakarta, 55281

Email: nelsiani_tobungan@mail.uajy.ac.id,nelsitobungan@gmail.com

\begin{abstract}
Betta fish (Betta splendens) is one of ornamental fishes which are popular in Indonesia. Its enthusiasts increase because of the development of technology and marketing, both online and offline. Selections of improper food cause the fish to grow slower than its size according to the age. One commonly used alternative food is natural food such as mosquito larvae, blood worms, (larvae Chironomus sp.) and Moina sp. This study examines the effectiveness of the natural food on the growth of Betta fish. This research used a completely randomized design, with three treatments, and each treatment had three replications. Samples of each treatment were 5 threemonth-old female Betta fish. The fish were treated for 4 weeks, with fish biomass measured each week. Additional parameters were pH, temperature and dissolved oxygen (DO). The different types of natural food had no different effect on the growth of Betta fish. Biomass growth of Betta fish fed with mosquito larvae was 2.04 grams; the one fed with blood worms (larvae Chironomus sp.) 2.15 grams and with Moina sp. 1.9 grams. pH water was in range of 6-7, while the temperature was at $26-27^{\circ} \mathrm{C}$ and DO 4,06-7,54ppm.
\end{abstract}

Keywords: Betta splendens, mosquito larvae, blood worms (larvae Chironomus sp.). Moina sp.

Abstrak

Ikan Cupang (Betta splendens) merupakan salah satu jenis ikan hias yang digemari di Indonesia. Peminat ikan ini bertambah seiring perkembangan teknologi dan pemasaran, baik secara online maupun offline. Pemilihan pakan yang kurang tepat menyebabkan pertumbuhan ikan yang tidak sesuai dengan usia ikan. Salah satu alternatif makanan yang biasa dipakai adalah pakan alami berupa jentik nyamuk, cacing darah (Larva Chironomus sp.) dan Moina sp. Penelitian ini mengkaji efektifitas pakan alami tersebut terhadap pertumbuhan ikan Cupang. Penelitian menggunakan Rancangan Acak Lengkap, dengan 3 perlakuan, dan setiap perlakuan memiliki 3 ulangan. Sampel tiap perlakuan adalah 5 ekor ikan Cupang betina usia 3 bulan. Pemeliharaan selama 4 minggu, dengan pengukuran biomassa ikan setiap minggu. Parameter tambahan adalah pH, suhu dan oksigen terlarut (DO). Perbedaan jenis pakan alami tidak memberikan pengaruh yang berbeda pada pertumbuhan ikan Cupang Pertumbuhan biomassa ikan Cupang dengan pakan jentik nyamuk adalah 2,04 gram, pakan Cacing darah (Larva Chironomus sp.) 2,15 gram dan dengan pakan alami Moina sp. 1,9 gram. pH air pada kisaran 67, sementara suhu pada $26-27^{\circ} \mathrm{C}$ dan DO 4,06-7,54ppm.

Kata kunci: Ikan Cupang, Jentik Nyamuk, Cacing Darah (Larva Chironomus sp.), Moina sp.

Diterima: 10 September 2016, disetujui: 30 September 2016

\section{Pendahuluan}

Ikan cupang dengan nama ilmiah Betta splendens merupakan salah satu jenis ikan hias yang berasal dari Asia tenggara. Ikan ini pertama kali ditemukan di Thailand dan Malaysia, dan sampai saat ini juga dibudidayakan sebagai salah satu ikan hias di Indonesia (Susanto, 1992). Ikan 
cupang adalah salah satu jenis ikan hias yang digemari, bukan hanya untuk sekedar hobi bagi pecinta ikan hias melainkan untuk keperluan kontes atau perlombaan. Peminat ikan ini bertambah seiring dengan perkembangan teknologi dan pemasaran, terlihat dari makin banyaknya toko-toko online maupun offline yang memperjualbelikan jenis ikan ini.

Pemeliharaan ikan Cupang memerlukan perawatan dan perhatian yang lebih jika dibanding dengan ikan-ikan konsumsi pada umumnya. Salah satu faktor yang harus dikontrol dalam pemeliharaannya adalah ketersediaan dan jenis pakan yang memadai dan mencukupi kebutuhan nutrisi untuk pertumbuhan dan perkembangannya. Berdasarkan survei yang telah dilakukan pada beberapa toko ikan hias dan pembudidaya ikan Cupang di Yogyakarta, diketahui ada dua jenis pakan yang biasa digunakan yaitu pakan alami dan buatan. Pakan buatan yang dimaksud adalah pakan dalam bentuk pellet, sementara pakan alami yang biasa digunakan diantaranya jentik nyamuk, Moina sp. atau yang dikenal masyarakat dengan kutu air dan cacing darah yang tidak lain adalah larva Chironomus sp..

Akibat pemberian pakan buatan adalah pertumbuhan dan perkembangan ikan Cupang tidak maksimal atau tidak sesuai dengan usianya. Oleh sebab itu, pembudidaya lebih memilih menggunakan pakan alami. Ketersediaan pakan, sampai pemilihan pakan yang tepat untuk menjamin kelangsungan hidup ikan, adalah hal yang penting diperhatikan agar pertumbuhan dan perkembangan ikan Cupang menjadi lebih pesat. Pakan alami yang akan diuji efektifitasnya adalah jentik nyamuk, cacing darah (Larva Chironomus sp.) dan Moina sp..

Hipotesis yang akan diuji dalam penelitian ini ada 2, yaitu pemberian pakan alami yang berbeda diduga tidak berpengaruh terhadap pertumbuhan ikan Cupang (Betta splendens) dan pemberian pakan alami yang berbeda diduga berpengaruh terhadap pertumbuhan ikan Cupang (Betta splendens).

\section{Metode Penelitian}

Penelitian ini menggunakan rancangan acak lengkap (RAL) dengan 3 perlakuan dan masing-masing perlakuan 3 ulangan. Perlakuan yang dimaksud adalah pemberian pakan akami jentik nyamuk, cacing darah (Larva Chironomus sp.) dan Moina sp. Prosedur penelitian meliputi:

\section{Tahap Adaptasi}

Ikan Cupang yang digunakan sebagai sampel terlebih dahulu diadaptasikan dengan lingkungan penelitian dan pakan uji selama 3 hari. Hal tersebut dilakukan agar ikan Cupang terbiasa dengan kondisi lingkungan penelitian dan pakan uji yang akan diberikan. Air yang digunakan sebagai media adalah air sumur yang diberi daun ketapang kering (Agus $d k k$., 2010), kemudian diendapkan selama 1 malam. Hal tersebut dilakukan untuk menjaga kondisi kesehatan ikan Cupang.

\section{Tahap Pengamatan dan Pengumpulan Data}

Ikan Cupang kemudian dimasukkan ke dalam wadah pemeliharaan dengan kepadatan 5 ekor/wadah pemeliharaan. Pakan yang diberikan disesuaikan dengan perlakuan. Pemberian pakan dilakukan 3 kali sehari dan sebelum diberi pakan, pakan diberi 6 tetes methylene blue. Lama pemeliharaan adalah 4 minggu. Hal yang diamati adalah penambahan biomassa ikan Cupang tiap perlakuan dengan melakukan penimbangan tiap 1 minggu sekali dengan timbangan analitik. Untuk mengetahui kualitas air yang digunakan dilakukan pengukuran suhu, pH dan DO yang dilakukan 1 kali setiap hari.

\section{Analisis Data}

Pertambahan Biomassa ikan Cupang dihitung dengan menggunakan rumus Effendie (1997) yaitu:

$$
\mathrm{W}=\mathrm{Wt}-\mathrm{W}_{0}
$$

Keterangan:

W : Pertambahan biomassa ikan (g)

Wt : Berat ikan uji pada akhir penelitian $(\mathrm{g})$

$\mathrm{W}_{0}$ : Berat ikan uji pada awal penelitian $(\mathrm{g})$

Data yang diperoleh dianalisis dengan menggunakan analisis ragam dengan one way Anova untuk melihat ada tidaknya pengaruh perlakuan terhadap pertumbuhan ikan Cupang. Sebelum dilakukan analisis ragam terlebih dahulu dilakukan uji normalitas dan 
homogenitas ragam data pertumbuhan yang diperoleh. Jika hasil analisis ragam menunjukkan ada perbedaan pengaruh antar perlakuan, maka dilanjutkan dengan uji Tukey untuk mengetahui beda nilai tengah (Srigandono, 1983). Sementara untuk data kualitas air akan dianalisis secara deskriptif.

\section{Hasil dan Pembahasan}

Data biomassa ikan Cupang yang diperoleh selama 4 minggu waktu pemeliharaan disajikan dalam Tabel 1.

Data pada Tabel 1, kemudian diuji untuk melihat normalitas dan homogenitas data yang diperoleh dengan $\alpha=0,05$. Berdasarkan uji Liliefors diketahui bahwa data terdistribusi normal dengan nilai signifikansi seluruh variable
0,200, dan uji homogenitas dengan One Way Anova menunjukkan data homogen dengan signifikansi 0,430.

Berdasarkan data pada Tabel 1. Diperolah data pertumbuhan biomassa ikan Cupang tiap perlakuan (Tabel 2).

Dari data pertumbuhan biomassa ikan pada Tabel 2, diketahui rata-rata pertumbuhan biomassa ikan tiap perlakuan. Rata-rata pertumbuhan biomassa ikan Cupang masingmasing perlakuan disajikan dalam Gambar 1. Data pertumbuhan biomassa ikan kemudian dianalisis dengan uji one-way Anova dengan membandingkan $\mathrm{F}$ hitung dan $\mathrm{F}$ tabel dengan $\alpha=$ 0,05 . Nilai $F$ hitung 0,757 , sementara nilai $F$ tabel adalah 3,220. Karena $\mathrm{F}$ hitung $\leq \mathrm{F}$ tabel, maka Ho diterima.

Tabel 1. Data Biomassa Ikan Cupang Selama Pemeliharaan

\begin{tabular}{|c|c|c|c|c|c|c|}
\hline \multirow[t]{2}{*}{ Perlakuan } & \multirow[t]{2}{*}{ "Ulangan } & \multicolumn{5}{|c|}{ Biomassa ikan (g) } \\
\hline & & $\begin{array}{c}\text { Minggu } \\
\text { ke-0 }\end{array}$ & $\begin{array}{c}\text { Minggu } \\
\text { ke-1 }\end{array}$ & $\begin{array}{c}\text { Minggu } \\
\text { ke-2 }\end{array}$ & $\begin{array}{c}\text { Minggu } \\
\text { ke-3 } \\
\end{array}$ & $\begin{array}{c}\text { Minggu } \\
\text { ke-4 } \\
\end{array}$ \\
\hline \multirow[t]{3}{*}{ Jentik Nyamuk } & 1 & 3,66 & 4,18 & 4,95 & 5,41 & 6,18 \\
\hline & 2 & 3,06 & 4,03 & 4,37 & 4,56 & 5,01 \\
\hline & 3 & 4,25 & 4,55 & 4,71 & 4,96 & 5,89 \\
\hline Cacing darah (Larva & 1 & 4,47 & 4,54 & 4,93 & 5,95 & 6,73 \\
\hline \multirow[t]{2}{*}{ Chironomus sp.) } & 2 & 3,62 & 3,36 & 3,85 & 4,50 & 5,81 \\
\hline & 3 & 4,13 & 4,28 & 4,81 & 5,11 & 6,12 \\
\hline \multirow[t]{3}{*}{ Moina sp. } & 1 & 4,35 & 4,48 & 5,26 & 6,33 & 6,67 \\
\hline & 2 & 2,86 & 3,33 & 3,79 & 3,81 & 4,03 \\
\hline & 3 & 3,30 & 3,51 & 3,83 & 4,31 & 5,73 \\
\hline
\end{tabular}

Tabel 2. Data Pertumbuhan Biomassa Ikan

\begin{tabular}{lcccc}
\hline \hline \multirow{2}{*}{ Ulangan } & \multicolumn{4}{c}{ Perlakuan } \\
\cline { 2 - 5 } & Jentik Nyamuk (g) & Cacing darah (Larva Chironomus sp.) (g) & Moina sp. $(\mathbf{g})$ \\
\hline \hline 1 & 2,52 & 2,26 & 2,32 \\
2 & 1,96 & 2,19 & 1,17 \\
3 & 1,64 & 1,99 & 2,43 \\
\hline Total & 6,12 & 6,44 & 5,92 \\
\hline Rata-Rata & 2,04 & 2,15 & 1,9 \\
\hline \hline & Data lain yang diperoleh selain data & variasi perlakuan pakan alami yang \\
biomassa adalah data pH, suhu dan DO air. & menunjukkan pertumbuhan biomassa yang lebih \\
Data-data tersebut disajikan dalam Tabel 3. & besar adalah pakan alami cacing darah. Meski \\
\multicolumn{1}{c}{ Berdasarkan Gambar 1. Diketahui } & demikian, hasil pengujian nilai F hitung dan F \\
perlakuan pakan alami jentik nyamuk & tabel menunjukkan bahwa pemberian pakan \\
menunjukkan rata-rata pertumbuhan biomassa & alami yang berbeda tidak memberikan pengaruh \\
2,04 gram, perlakuan pakan alami darah (Larva & berbeda terhadap pertumbuhan ikan Cupang
\end{tabular}

Chironomus sp.) 2,15 gram dan pakan alami Moina sp. 1,9 gram. Data tersebut menunjukkan 
(Betta splendens). Karena hasil uji ragam dengan one-way Anova yang menunjukkan perlakuan pakan alami yang berbeda tidak berbeda nyata, sehingga uji Tukey tidak dilaksanakan. Hasil yang tidak berbeda nyata dipengaruhi oleh nutrisi yang terkandung di dalam ketiga pakan alami tersebut yang jumlahnya sama-sama tinggi. Adapun kandungan nutrisi pada masing-masing pakan dapat dilihat pada Tabel 4 .

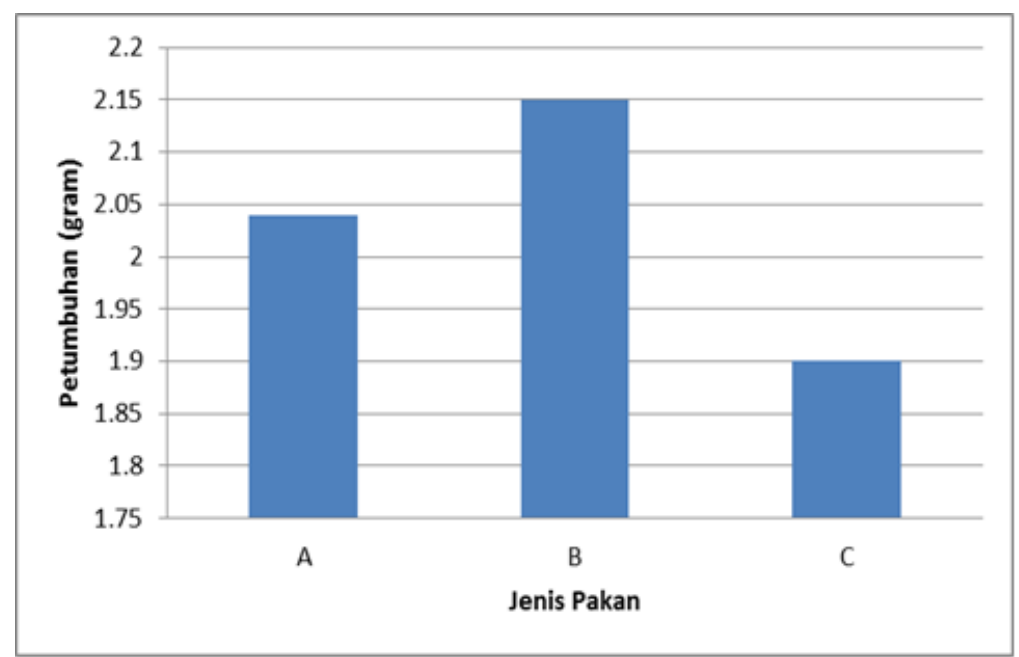

Gambar 1. Histogram rata-rata pertumbuhan ikan Cupang Keterangan: $\mathrm{A}=$ Jentik Nyamuk, $\mathrm{B}=\mathrm{Cacing}$ Darah (Larva Chironomus sp.) $\mathrm{C}=$ Moina sp.

Tabel 3. Hasil Pengukuran Kualitas Air Selama Penelitian

\begin{tabular}{ccc}
\hline \hline No & Parameter & Hasil \\
\hline \hline 1 & $\mathrm{pH}$ & $6-7$ \\
2 & Suhu & $26-27^{\circ} \mathrm{C}$ \\
3 & $\mathrm{DO}$ & $4,06-7,54 \mathrm{ppm}$ \\
\hline
\end{tabular}

Tabel 4. Kandungan Nutrisi Jentik Nyamuk, Cacing Darah dan Moina sp.

\begin{tabular}{lccc}
\hline \hline \multirow{2}{*}{ Jenis Nutrisi Pakan } & \multicolumn{3}{c}{ Kandungan Nutrisi (\%) } \\
\cline { 2 - 4 } & Jentik Nyamuk & Cacing darah (Larva Chironomus sp.) $* * *$ & Moina sp. ***** \\
\hline \hline Protein & $48,72^{*}$ & 47,8 & 37,38 \\
Lemak & $13,50^{*}$ & 9,7 & 13,29 \\
Air & $68,18^{* *}$ & 90,1 & 99,6 \\
Abu & $1,4^{* *}$ & 4,5 & 11 \\
\hline \hline
\end{tabular}

\section{Keterangan:}

* $\quad$ : Sumber Dahelmi (2001)

** $\quad$ : Sumber Agus $d k k$., (2010)

*** : Sumber McWilliams (2008)

*** : Sumber Wijayanti (2010)

Berdasarkan Tabel 4. Jenis pakan alami yang memiliki kandungan protein paling tinggi adalah Jentik nyamuk, kemudian cacing darah (Larva Chironomus sp.), dan yang paling sedikit kandungan proteinnya Moina sp.. Kandungan lemak yang paling besar terdapat juga pada jentik nyamuk, kemudian pada Moina sp. dan lemak paling sedikit terdapat pada cacing darah

(Larva Chironomus sp.). Meskipun jumlah kandungan protein berbeda, akan tetapi jumlahnya tidak berbeda jauh. Kandungan protein ketiga pakan alami ini terbilang tinggi, sehingga baik diaplikasikan sebagai alternatif pakan alami. Jumlah protein yang dibutuhkan ikan Cupang dalam masa pertumbuhannya adalah pada kisaran 50\%. Protein dibutuhkan 
untuk pembentukan, pertumbuhan dan perkembangan jaringan serta juga berperan sebagai sumber energi. Sehingga jika dihubungkan dengan informasi dalam Tabel 4, pakan dengan kandungan protein tinggi seperti jentik nyamuk dan cacing darah sangat baik digunakan dalam masa pertumbuhan. Kandungan lemak dalam pakan juga dibutuhkan dalam masa pertumbuhan sebagai sumber energi (Sukamti, 1994). Lemak yang kurang jumlahnya dalam pakan mengakibatkan fungsi lemak sebagai sumber energi digantikan oleh protein sehingga jumlah protein untuk pertumbuhan menjadi berkurang, yang berakibat pada tidak optimalnya pertumbuhan.

Faktor yang berpengaruh dalam pertumbuhan ikan selain faktor gen juga dipengaruhi oleh kandungan nutrisi dalam pakan dan kualitas air yang digunakan dalam pemeliharaan serta yang tidak kalah penting adalah kesesuaian ukuran bukaan mulut ikan dengan ukuran pakan. Ukuran pakan yang sesuai dengan bukaan mulut ikan akan meningkatkan efisiensi pakan serta meningkatkan pertumbuhan (Priyadi $d k k .$, 2010). Ukuran jentik nyamuk adalah 10-25mm (Agus dkk., (2010)), cacing darah (Larva Chironomus sp.) $1 \mathrm{~mm}-2 \mathrm{~cm}$ (Johnson \& Krieger, (2005)), Moina sp. 5001.000 mikron (Mudjiman, (2008)). Hasil penelitian ini yang menunjukkan pertumbuhan biomassa yang paling besar adalah pada perlakuan pakan Cacing darah (Larva Chironomus sp.). Sehingga dapat dikatakan bahwa cacing darah sesuai dengan ukuran bukaan mulut ikan Cupang usia 3 bulan. Perlakuan pakan dengan Moina sp. menunjukkan pertumbuhan biomassa yang paling kecil. Hal tersebut selain diakibatkan jumlah protein yang lebih sedikit dibanding perlakuan jenis pakan alami yang lain, juga dapat diakibatkan oleh ukuran Moina sp. yang sangat kecil jika dibandingkan dengan bukaan mulut ikan Cupang, sehingga tingkat konsumsi pakan menjadi rendah, yang berakibat pada rendahnya pertumbuhan biomassa. Sehingga pakan ini menjadi tidak efektif untuk menunjang pertumbuhan ikan Cupang usia 3 bulan.

Kualitas air selama pemeliharaan juga berpengaruhi terhadap daya tahan dari ikan Cupang. Oleh sebab itu kualitas air selalu dipantau dengan mengukur $\mathrm{pH}$, Suhu dan oksigen terlarut (DO). Selain itu air juga diganti setiap 3 hari sekali untuk memastikan air tetap dalam kualitas yang baik. Data kualitas air pada Tabel 3, menunjukkan bahwa $\mathrm{pH}$ air selama pemeliharaan ada pada kisaran 6-7, sementara suhu pada $26-27^{\circ} \mathrm{C}$ dan DO 4,06-7,54 ppm. Setyowati (2014), menyebutkan bahwa lingkungan perairan yang paling cocok untuk pemeliharaan ikan hias, termasuk ikan Cupang adalah pada $\mathrm{pH}$ 6-7, suhu $26-27^{\circ} \mathrm{C}$ dan $\mathrm{DO}>$ 3ppm. Sehingga dapat dikatakan bahwa kualitas air yang digunakan dalam penelitian ada dalam kondisi yang baik, sehingga memungkinkan ikan Cupang untuk tetap hidup. $\mathrm{pH}$ berpengaruh terhadap pertumbuhan. $\mathrm{pH}$ air di bawah 4,5 menyebabkan pertumbuhan terhambat karena air dikategorikan bersifat toksik bagi ikan. $\mathrm{pH}$ paling baik untuk pertumbuhan adalah pada kisaran 6,5-9,0 (SITH-ITB, 2009). Suhu juga ikut berpengaruh terhadap pertumbuhan ikan. Suhu dipengaruhi oleh jumlah amoniak yang terdapat pada air, sehingga mempengaruhi kualitas air. Amoniak berasal dari zat sisa yang dikeluarkan oleh ikan itu sendiri. Suhu optimum yang mendukung pertumbuhan ikan adalah pada kisaran suhu $25-26^{\circ} \mathrm{C}$ (Tsuji $d k k$., 2014).

DO air yang digunakan dalam pemeliharaan tidak kalah pentingnya untuk selalu diukur. DO menunjukkan jumlah oksigen terlarut dalam air. Oksigen dibutuhkan dalam proses respirasi dan oksidasi. Ikan Cupang merupakan ikan yang memiliki toleransi terhadap DO yang cukup tinggi. Sehingga ikan ini dapat tetap hidup dalam lingkungan dengan jumlah oksigen yang tidak terlalu melimpah. Hal ini disebabkan karena ikan ini merupakan kelompok ikan labirin terbesar (Fahmi dkk., 2015). Labirin adalah alat pernafasan tambahan yang dimiliki oleh beberapa ikan. Labirin memungkinkan ikan mampu mengikat oksigen langsung dari udara. Sehingga dengan kondisi oksigen yang minim, ikan tidak menjadi stress (Ahmadi dkk., 2012).

\section{Simpulan}

Perbedaan jenis pakan alami tidak memberikan pengaruh berbeda terhadap pertumbuhan ikan Cupang (Betta spendens). Pertumbuhan biomassa ikan Cupang (Betta 
spendens) yang diberi pakan jentik nyamuk adalah 2,04 gram, yang diberi pakan Cacing darah (Larva Chironomus sp.) 2,15 gram dan dengan pakan alami Moina sp. 1,9 gram.

\section{Ucapan Terima Kasih}

Terima kasih kepada Universitas Atma Jaya Yogyakarta yang telah memberikan dana hibah penelitian internal, sehingga penelitian ini dapat terlaksana dengan baik.

\section{Daftar Pustaka}

Agus, M., Yusufi, M.T. dan Nafi, B. 2010. Pengaruh Perbedaan Jenis pakan Alami Daphnia, Jentik Nyamuk dan Cacing Sutera Terhadap Pertumbuhan Ikan Cupang Hias (Betta Splendens). PENA Akuatika, 2 (1): 21-29.

Ahmadi, H., Iskandar dan Kurniawati. 2012. Pemberian Probiotik dalam Pakan Terhadap Pertumbuhan Lele Sangkuriang (Clarias gariepinus) pada Pendedaran II. Jurnal Perikanan dan Kelautan, 3 (4): 99-107.

Dahelmi. 2001. Usaha pembenihan ikan hias air tawar. Penebar Swadaya, Jakarta.

Effendie, M.I. 1997. Biologi Perikanan. Yayasan Pustaka Nusatama. Yogyakarta

Fahmi, R.M., Ginanjar, R. dan Kusumah, R.V. 2015. Keragaman Ikan Hias di Lahan Gambut Cagar Biosfer Bukit-Batu, Provinsi Riau. Prosiding Seminar Nasional Masyarakat Biodiversitas Indonesia, 1 (1): 51-58.

Johnson, N.J. dan Krieger, K.A. 2005. Atlas of The Chironomid Midges. USA: Water Quality Laboratory, Heidelberg College, Tiffin, Ohio.

McWilliams, D.A. 2008. Nutrition Recommendations for Some Captive Amphibians Spesies (Anura dan
Caudata). Canada: Canadian Association of Zoos and Aquariums.

Mudjiman, A. 2008. Makanan Ikan. Jakarta : Penebar Swadaya.

Priyadi, A., Kusrini, E. dan Megawati, T. 2010. Perlakuan Berbagai Jenis Pakan Alami untuk Meningkatkan Pertumbuhan dan Sintasan Larva Ikan Upside down Catfish (Synodontis nigriventris). Prosiding Forum Inovasi Teknologi Akuakultur.

Setyowati, RR. I., Naswati, W., Heatiningsih, Miftakhodin, Cahyadi, Ayu D. 2014. Prakarya dan Kewirausahaan. Jakarta: Pusat Kurikulum dan Perbukuan, Balitbang, Kemdikbud.

SITH-ITB. 2009. Teknologi Pengelolaan Kualitas Air, Progam Alih Jenjang D4 Bidang Akuakultur. SITH, ITB-VEDCA-SEAMOLEC.

Srigandono, B. 1983. Rancangan Percobaan (Experimental Design). Semarang: Fakultas Peternakan, Universitas Diponegoro.

Sukamti, E.R.1994. Pengaruh Gizi Terhadap Pertumbuhan dan Perkembangan Anak. Jakarta: Cakrawala Pendidikan.

Susanto, H. 1992. Memelihara Cupang. Penerbit Kanisius. Yogyakarta.

Tsuji, M., Abe, H., Hanyuu, K., Kuriyama, I., Tsuchihashi, Y., Tsumoto, K., Nigou, T., Kasuya, T., Katou, T., Kawamura, T., Okada, K., Uji, S. dan Sawada, Y. 2014. Effect of temperature on survival, growth and malformation of cultured larvae and juveniles of the grouper Epinephelus septemfasciatus. Fisheries Science, 80( 1): 6981.

Wijayanti, K. 2010. Pengaruh Pemberian Pakan Alami yang Berbeda Terhadap Sintasan dan Pertumbuhan Benih Ikan Palmas (Polypterus senegalus senegalus Cuvier, 1829). Depok: FMIPA Universitas Indonesia. 